\title{
Maternal Stress Produces Learning Deficits Associated with Impairment of NMDA Receptor-Mediated Synaptic Plasticity
}

\author{
Gi Hoon Son, ${ }^{1 *}$ Dongho Geum, ${ }^{2 \star}$ Sooyoung Chung, ${ }^{1}$ Eun Joo Kim, ${ }^{3}$ Ji-Hoon Jo, ${ }^{5}$ Chang-Mee Kim, ${ }^{4}$ Kun Ho Lee, ${ }^{1}$ \\ Hyun Kim, ${ }^{4}$ Sukwoo Choi, ${ }^{1}$ Hyun Taek Kim, ${ }^{3}$ Chang-Joong Lee, ${ }^{5}$ and Kyungjin Kim ${ }^{1}$ \\ ${ }^{1}$ School of Biological Sciences, Seoul National University, Seoul 151-742, Korea, ${ }^{2}$ Graduate School of Medicine, ${ }^{3}$ Department of Psychology, and ${ }^{4}$ College of \\ Medicine, Korea University, Seoul 136-705, Korea, and ${ }^{5}$ Department of Biology, Inha University, Inchon 402-752, Korea
}

\begin{abstract}
Stress in adulthood can have a profound effect on physiology and behavior, but the extent to which prolonged maternal stress affects the brain function of offspring when they are adult remains primarily unknown. In the present work, chronic immobilization stress to pregnant mice affected fetal growth and development. When pups born from stressed mice were reared to adulthood in an environment identical to that of nonstressed controls, several physiological parameters were essentially unaltered. However, spatial learning and memory was significantly impaired in the maternally stressed offspring in adulthood. Furthermore, electrophysiological examination revealed a significant reduction in NMDA receptor-mediated long-term potentiation in the CA1 area of hippocampal slices. Subsequent biochemical analysis demonstrated a substantial decrease in NR1 and NR2B subunits of the NMDA receptor in synapses of the hippocampus, and the interaction between these two subunits appeared to be reduced. These results suggest that prolonged maternal stress leads to long-lasting malfunction of the hippocampus, which extends to and is manifested in adulthood.
\end{abstract}

Key words: maternal stress; hippocampus; learning and memory; synaptic plasticity; long-term potentiation; LTP; NMDA receptor

\section{Introduction}

The environment in early life can have a major impact on later life. For instance, low birth weight caused by malnutrition seems to strongly correlate with risk of cardiovascular and metabolic disorders. To account for such long-term effects of environmental factors, the concept of early life "programming" has been proposed (Nathanielsz, 1999; Welberg and Seckl, 2001).

The most extensively studied system susceptible to environmental programming in early life is the hypothalamus-pituitaryadrenal (HPA) axis. This neuroendocrine axis regulates a variety of metabolic processes by secreting glucocorticoids (GCs) in response to stress and diurnal cues. Elevated GCs exert negative feedback on the hypothalamus either directly or via other brain regions (Stratakis and Chrousos, 1995). In the rat, maternal stress or exposure to a high level of GCs during pregnancy sensitizes HPA activity to stress in adulthood (Barbazanges et al., 1996). In contrast, early adoption, neonatal handling, or a high level of spontaneous maternal care can elicit the opposite effect (Maccari et al., 1995; Vallee et al., 1997; Francis et al., 1999). The programming effects of environmental factors on the HPA axis are thought to be achieved by regulating the expression of corticosteroid receptors in the hippocampus, a brain area that plays a cru-

Received March 9, 2004; revised Jan. 6, 2006; accepted Feb. 12, 2006.

This work was supported by grants from the Korea Ministry of Science and Technology through the Brain Research Center of the 21st Century Frontier Research Program. G.H.S. and S. Chung were supported by Brain Korea 21 Research Fellowships from the Korea Ministry of Education.

${ }^{*}$ G.H.S. and D.G. contributed equally to this work.

Correspondence should be addressed to Dr. Kyungjin Kim, School of Biological Sciences, Seoul National University, Seoul 151-742, Seoul, Korea. E-mail: kyungjin@snu.ac.kr.

DOI:10.1523/JNEUROSCI.3850-05.2006

Copyright $\odot 2006$ Society for Neuroscience $\quad$ 0270-6474/06/263309-10\$15.00/0 cial role in terminating stress responses (Barbazanges et al., 1996; Levitt et al., 1996; De Kloet et al., 1998; Francis et al., 1999).

Besides the imprinting effect on HPA reactivity, maternal stress has a variety of deleterious effects on the developing fetus. Stress during pregnancy has been shown to provoke abortion and reduce litter size. It can also cause physiological defects in the offspring such as hypoxia, arterial hypertension, and bradycardia (Welberg and Seckl, 2001). Furthermore, neurological and behavioral abnormalities, such as hyperactivity, altered emotional reactivity, and cognitive defects, have been reported, although there are some differences among experimental models. For example, it was reported that repeated immobilization stress to pregnant rats during the last week of pregnancy produced spatial learning deficits in the offspring associated with inhibition of neurogenesis in the hippocampus (Lemaire et al., 2000). In contrast, other studies using a similar experimental model showed that maternal stress induced high anxiety-like behavior in adult offspring without any influence on spatial learning (Vallee et al., 1997). It was also shown that repeated emotional stress on the 19th day of pregnancy is sufficient to induce a defect in conditioned memory but not anxiety (Lordi et al., 2000).

However, most studies thus far have examined the effect of acute or relatively short-term stressors and have attempted to correlate the defects in learning capability with alterations in HPA reactivity and/or anatomical changes. In the present study, we explored the long-lasting effect of prolonged maternal stress during pregnancy, as described in our recent study (Chung et al., 2005), on hippocampus-dependent learning and memory in adult offspring and the possible cellular and molecular mechanisms involved. 


\section{Materials and Methods}

Maternal stress procedure. ICR mice, obtained from the Laboratory Animal Center at Seoul National University, were used in all experiments and kept in temperature-controlled $\left(22-23^{\circ} \mathrm{C}\right)$ quarters under a $12 \mathrm{~h}$ light/dark photoperiod (lights on at 7:00 A.M.); standard mouse chow and water were available ad libitum. The maternal stress procedure was performed as described previously (Chung et al., 2005). Briefly, pregnant ICR mice were prepared by mating with males at the age of 6-7 weeks. Mice in the stress group were placed, individually, in a restrainer (a transparent plastic cylinder, $3 \mathrm{~cm}$ in diameter and $9 \mathrm{~cm}$ long) daily for $6 \mathrm{~h}$ (10:00 A.M. to 4:00 P.M.) from $8.5 \mathrm{~d}$ postcoitum (dpc) to 18.5 or $19.5 \mathrm{dpc}$ (the day before parturition). Control pregnant mice remained undisturbed. The pups born to stressed mice (STR) were weaned on postnatal day 21 (P21) and reared in an environment identical to that of the controls (CTL). Male offspring was used in all experiments. For crossfostering experiments, control neonates were adopted to stressed mothers (adopted CTL), and neonates from stressed mice were adopted to control mothers (adopted STR) on the second postnatal day. All animal procedures were approved by the Animal Care and Use Committee of Seoul National University.

Measurement of serum corticosterone and norepinephrine. Mice were killed between 1:00 P.M. and 2:00 P.M. in all experiments, and their trunk blood was collected and centrifuged at $10,000 \times g$ for $20 \mathrm{~min}$ to obtain sera. Corticosterone (CS) levels were assayed using a commercial radioimmunoassay kit according to the instructions of the manufacturer (Diagnostic Products, Los Angeles, CA). Serum concentrations of norepinephrine were determined by HPLC coupled to an electrochemical detector (HPLC-ECD) system (Gilson, Middleton, WI) (Kang et al., 1998). Briefly, serum samples were diluted in $0.1 \mathrm{~N}$ perchloric acid (Sigma, St. Louis, MO) containing 0.04 m sodium metabisulfite (Sigma) and centrifuged at $10,000 \times g$; the supernatants were recovered, microfiltered, and subjected to HPLC-ECD.

Synthesis of cDNA clones. cDNA fragments for in situ hybridization were amplified by reverse transcription (RT)-PCR and cloned into pGEM-T vector (Promega, Madison, WI). The clones were confirmed by sequencing using the chain-termination DNA sequencing method. Sequences of the primers for RT-PCR were as follows: glucocorticoid receptor (GR) (GenBank accession number M14053) upper, 5'-CGAGAGTCCTTGGAGGTCAG-3'; GR lower, 5' -TAGAAAACACTGAGCGGCCT-3'; mineralocorticoid receptor (MR) (GenBank accession number M36074) upper, 5'TCAGACCTTGGAGCGTTCTT-3'; MR lower, 5' -AGTGTGGAGGACCTGTGACC-3'; NMDA receptor subunit 1 (NR1) (GenBank accession number NM008169) upper, 5'-GCTGTACCTGCTGGACCGCT-3'; NR1 lower, 5' -GCAGTGTAGGAAGCCACGATGATC-3'; NR2A (GenBank accession number NM008170) upper, 5'-GCTACGGGCAGACAGAGAAG3'; NR2A lower, 5' -GTGGTTGTCATCTGGCTCA-3'; NR2B (GenBank accession number NM008171) upper, 5'-GCTACAACACCCACGAGAAGAGG-3'; and NR2B lower, 5' -GAGAGGGTC CACACTTTCC-3'.

In situ hybridization. In situ hybridization was performed as described previously (Sun et al., 2005). Briefly, mouse brain samples from embryonic day 18.5 fetuses and 3- and 7-week-old offspring were immediately frozen in prechilled isopentane (Sigma). Frozen sections (12 $\mu \mathrm{m}$ thick) were cut coronally and thaw mounted onto gelatin-coated slides. The sections were fixed in $4 \%$ formaldehyde, dehydrated in increasing concentrations of ethanol, and air dried. Antisense cRNA probes were prepared by transcription with RNA polymerase, using a Riboprobe system (Promega), in the presence of $\left[\alpha^{-}{ }^{35} \mathrm{~S}\right] \mathrm{UTP}(1000-1500 \mathrm{Ci} / \mathrm{mmol}$; Amersham Biosciences, Cleveland, $\mathrm{OH}$ ). The sections were hybridized overnight at $52^{\circ} \mathrm{C}$ with $1.2 \times 10^{6} \mathrm{cpm}$ of labeled RNA probe per slide. They were then washed in $4 \times$ SSC, treated with RNase A $(20 \mu \mathrm{g} / \mathrm{ml}$; Boehringer Mannheim, Mannheim, Germany) for $30 \mathrm{~min}$ at $37^{\circ} \mathrm{C}$, and washed several times. After drying, the slides were autoradiographed for $7 \mathrm{~d}$ using $\beta$-max Hyperfilm (Amersham Biosciences).

The eight-arm radial maze task for spatial memory. The eight-arm radial maze task for spatial working memory was conducted as described previously, with modifications (Miyakawa et al., 2001). The floor of the maze was made of black Plexiglas, and the wall $(20 \mathrm{~cm}$ high $)$ consisted of transparent Plexiglas. Each arms $(8 \times 30 \mathrm{~cm})$ radiated from an octagonal central starting platform $(9 \times 8 \mathrm{~cm}$ perimeter $)$ like the spokes of a wheel. Identical wells $(0.8 \mathrm{~cm}$ deep and $1.2 \mathrm{~cm}$ in diameter) containing $0.1 \mathrm{ml}$ of $10 \%$ sucrose solution were placed at the distal end of each arm as rewards. The maze was elevated $60 \mathrm{~cm}$ above the floor and placed in a dimly lit room with several extramaze cues. During the experiment, the maze was maintained in a constant orientation. One week before pretraining, 6-week-old animals were habituated to a restricted water supply $(2 \mathrm{~h} / \mathrm{d}$ between 4:00 P.M. and 6:00 P.M.). Pretraining started on the day 8. Each mouse was placed in the central starting platform and allowed to explore and to consume rewards scattered over the whole maze for a $5 \mathrm{~min}$ period (two sessions per mouse). After completing the initial pretraining, the mice received another pretraining involving obtaining the reward from each well after being placed at the distal end of each arm. A trial was finished after the subject addressed the bait (independent of its consuming the bait) and returned to the central platform. This was repeated eight times, using the eight different arms, for each mouse. From the next day, actual maze acquisition trials were performed for $12 \mathrm{~d}$ between 11:00 A.M. and 4:00 P.M. each day. All eight arms were baited with sucrose solution. Mice were placed on the central platform and allowed to obtain all eight rewards within $5 \mathrm{~min}$. A session was terminated immediately after all eight rewards had been consumed or when $5 \mathrm{~min}$ had elapsed. An arm visit was defined as a journey of $>10 \mathrm{~cm}$ from the central platform. The mice were confined to the central platform for $5 \mathrm{~s}$ after each arm choice and underwent one session per day (12 sessions total). For each training session, choices of arms, numbers of revisits, omission errors, and time taken to complete a single trial (from entering an arm to returning to the central platform) were recorded.

Eight-arm radial maze task for stimulus-response habit learning. The eight-arm radial maze task for stress-response (S-R) habit learning was conducted as described previously with modifications (McDonald and Hong, 2004). An eight-arm radial maze of the same size with that used for spatial memory was used. The wall of each arm was constructed with black opaque Plexiglas, and small light bulbs, which could be turned on/off, were affixed on the inner side of each arm. Pretraining was performed as described above. During each trial, four randomly selected arms were lit, with a rule that no more than two adjacent arms could be lit. The location of lit arms was changed on every trial. Mice were trained to go to lit arms, which were baited with $0.1 \mathrm{ml}$ of sucrose solution, and to avoid darkened arms, which were not baited. Trials were run once a day, with each trial beginning when a mouse had been placed onto the central platform and confined for $5 \mathrm{~s}$. The trial ended when all of the bait was taken or $5 \mathrm{~min}$ had elapsed. Arm selections and numbers of omission errors were recorded.

Electrophysiology. Brains from 7- to 8-week-old males were dissected and placed in an ice-cold $\left(4^{\circ} \mathrm{C}\right)$ artificial CSF (ACSF) containing the following (in mM): $126 \mathrm{NaCl}, 3 \mathrm{KCl}, 23 \mathrm{NaHCO}_{3}, 1.4 \mathrm{KH}_{2} \mathrm{PO}_{4}, 1.8$ $\mathrm{CaCl}_{2} \cdot 2 \mathrm{H}_{2} \mathrm{O}, 1.3 \mathrm{MgSO}_{4}$, and 10 glucose. Transverse hippocampal slices (400 $\mu \mathrm{m}$ thickness) were prepared with a tissue chopper (HSE, MarchHugstetten, Germany), and allowed to stabilize for at least $2 \mathrm{~h}$ in a chamber containing ACSF, continuously bubbled with $95 \% \mathrm{O}_{2} / 5 \% \mathrm{CO}_{2}$, before being recorded in a submersion-type chamber at $30^{\circ} \mathrm{C}$. Field EPSPs (fEPSPs) were evoked by stimulating Schaffer collateral commissural fibers with monophasic square-wave pulses (100 $\mu$ s duration) delivered through a bipolar electrode and recorded with an ACSF-filled glass electrode (1-2 M $\Omega$; MTW120-4; World Precision Instruments, Sarasota, FL) using a DAM80 differential amplifier (World Precision Instruments). For a baseline recording, fEPSPs were evoked every $30 \mathrm{~s}$, and the stimulus intensity was adjusted to give similarly sized responses from slice to slice. The tetanus stimulus for inducing long-term potentiation (LTP) consisted of three trains of pulses at $100 \mathrm{~Hz}$ with an intertrain interval of $20 \mathrm{~s}$. Tetraethylammonium (TEA)-induced LTP was also examined as described previously (Hanse and Gustafsson, 1994) with a minor modification; for inducing LTP, hippocampal slices were exposed to $25 \mathrm{~mm}$ TEA for $10 \mathrm{~min}$. All data were normalized to the average response before TEA treatment and are presented as means \pm SEM.

Whole-cell patch-clamp recordings were performed in CA1 pyramidal neurons of hippocampal slices (200 $\mu \mathrm{m}$ thickness) prepared from 21- to 24 -d-old mice. Slices were transferred to a temperature-controlled $\left(30^{\circ} \mathrm{C}\right)$ dish and continuously perfused at a rate of $2-3 \mathrm{ml} / \mathrm{min}$ with $\mathrm{Mg}^{2+}$-free ACSF oxygenated with $95 \% \mathrm{O}_{2} / 5 \% \mathrm{CO}_{2}$. Whole-cell record- 
ings were made from visually identified CA1 neurons with glass micropipettes (5-10 M $\Omega$ tip resistance; MTW150-4; World Precision Instruments) using a 40- water-immersion objective attached to an Olympus Optical (Tokyo, Japan) (BX-50WI) upright microscope. The composition of the pipetting solution for the recordings was as follows (in $\mathrm{mM}$ ): $170 \mathrm{~K}$-gluconate, $10 \mathrm{HEPES}, 10 \mathrm{NaCl}, 2 \mathrm{MgCl}_{2}, 10 \mathrm{EGTA}$, and $3.5 \mathrm{Mg}$ ATP, pH 7.2. Ionic currents were recorded with an Axopatch 200A patch-clamp amplifier (Molecular Devices, Palo Alto, CA). Stimulation and on-line acquisition were performed using a signal generator (World Precision Instruments) and the pClamp program (Molecular Devices). Signals were filtered at $2 \mathrm{kHz}$ and digitized at $20 \mathrm{kHz}$.

Isolation of a postsynaptic density-enriched fraction. Biochemical fractionation was performed as described previously, with minor modifications (Moon et al., 1994). Dounce homogenates in ice-cold lysis buffer (in mm: 10 Tris, $\mathrm{pH} 8.1,1 \mathrm{MgCl}_{2}, 1 \mathrm{CaCl}_{2}, 1 \mathrm{NaF}, 1 \mathrm{Na}_{3} \mathrm{VO}_{4}, 10 \mathrm{PMSF}$, and $320 \mathrm{~mm}$ sucrose) were centrifuged at $1000 \times g$ to remove nuclei and large debris. The supernatants were centrifuged at $13,000 \times g$ to obtain crude plasma membrane fractions that were washed three times with lysis buffer and resuspended in wash/resuspension buffer (in mM: 10 Tris, $\mathrm{pH}$ 8.1, $1 \mathrm{NaF}, 1 \mathrm{Na}_{3} \mathrm{VO}_{4}, 10$ PMSF, and 320 sucrose). These were then loaded onto sucrose density gradients $(0.85-1.2 \mathrm{~m}$ sucrose) and centrifuged at $35,000 \times g$ for $2 \mathrm{~h}$. The synaptosomal membrane fractions sedimenting between 1 and $1.2 \mathrm{M}$ were treated with $1 \%$ Triton X-100 for $15 \mathrm{~min}$ on ice and pelleted again by centrifugation at 22,000 $\times \mathrm{g}$ for $1 \mathrm{~h}$ to yield the postsynaptic density (PSD)-enriched fractions.

Antibodies and immunoblotting. Anti-NR1 (PharMingen, San Diego, CA), anti-NR2B (Upstate, Charlottesville, VA), anti-PSD95 (Upstate), and anti-actin (Sigma) antibodies were obtained commercially. AntiNR2A antibody was kindly provided by Dr. I. S. Moon (Dongguk University, Kyungju, Korea). Hippocampal whole-cell extracts or appropriate subcellular fractions were resolved on SDS-polyacrylamide gels and transferred to polyvinylidene difluoride (PVDF) membranes (Millipore, Bedford, MA) in a Bio-Rad (Richmond, CA) Trans-Blot electrophoresis apparatus using Towbin's buffer (25 mm Tris, $\mathrm{pH} 8.3,192 \mathrm{~mm}$ glycine, and $20 \%$ methanol). The blots were blocked in Tris-buffered saline (TBS) (in mm: $150 \mathrm{NaCl}, 10$ Tris, $\mathrm{pH} 7.6$, and $2 \mathrm{MgCl}_{2}$ ) containing $0.5 \%$ Tween 20 and 3\% BSA and were incubated with primary antibody at room temperature for $1 \mathrm{~h}$. The blots were then washed four times with TBS/0.5\% Tween 20. Primary antibody binding was subsequently detected by incubation with secondary antibodies linked to horseradish peroxidase (Jackson ImmunoResearch, West Grove, PA). The blots were washed as described above, and immunoreactive bands were visualized with Amersham Biosciences ECL reagents according to the instructions of the manufacturer (Amersham Biosciences, Uppsala, Sweden). The blots were analyzed with Bio1D image analysis software (VilberLourmat, Marne-la-Vallée, France) and are expressed as relative optical densities (R.O.D.). Immunoreactivities were normalized with those of internal control proteins: actin for whole-cell lysates, PSD95 for PSDenriched fractions, and pulled-down primary target proteins for immunoprecipitation experiments, respectively.

Coimmunoprecipitation. For immunoprecipitation, groups of four to five hippocampi were homogenized in modified radioimmunoprecipitation assay (RIPA) buffer (20 mM Tris, pH 7.5, $150 \mathrm{~mm} \mathrm{NaCl,} \mathrm{1 \%} \mathrm{Triton} \mathrm{X-100,}$ and $10 \mathrm{~mm}$ PMSF), and the homogenates were incubated for $1 \mathrm{~h}$ on ice. Debris was removed by brief centrifugation at $10,000 \times g$ for $20 \mathrm{~min}$. One milligram of whole-cell lysate was precleared by incubation with protein A-Sepharose (Amersham Biosciences) and incubated with PSD95, NR1, $\mathrm{NR} 2 \mathrm{~A}$, or NR2B antibody for $2 \mathrm{~h}$ at $4^{\circ} \mathrm{C}$. The resulting complexes were captured with $10 \%$ protein A-Sepharose for $1 \mathrm{~h}$. The immunoprecipitates were subsequently washed three times with modified RIPA buffer and subjected to immunoblot analysis. Equal amounts of pulled-down target proteins were verified by preliminary immunoblot analysis using small aliquots of the immunoprecipitates, followed by densitometric image analysis.

Sucrose density gradient centrifugation. Hippocampal cell lysates were prepared by lysis in modified RIPA buffer with $2 \%$ Triton X-100. Sucrose density gradient ultracentrifugation of the lysates was performed using lysates layered on $6 \mathrm{ml}$ of continuous $10-40 \%(\mathrm{w} / \mathrm{v})$ sucrose gradients centrifuged for $16 \mathrm{~h}$ at $100,000 \times g$ at $4^{\circ} \mathrm{C}$. Twenty serial fractions were collected and analyzed by immunoblotting.
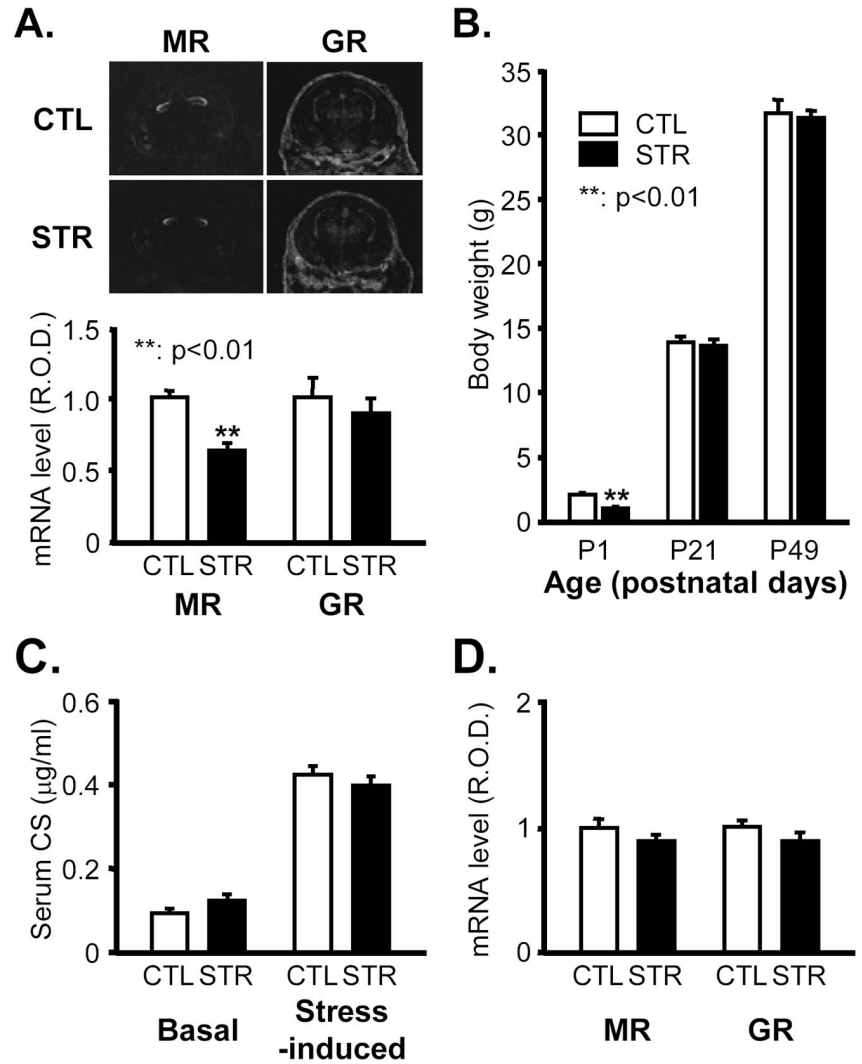

Figure 1. Physiological parameters of maternally stressed mice. $A, M R$ and GR mRNA levels $18.5 \mathrm{dpc}$ in the developing hippocampus of CTL and STR mice determined by in situ hybridization. Top panel shows representative photographs of in situ hybridizations. R.O.D. of hybridization signals in the hippocampal regions were quantified with Bio1D image analysis software and are represented an arbitrary units in the bottom panel ( ${ }^{* *} p<0.01 ; n=6$ for each group). $\boldsymbol{B}$, Body weights of mice at the age of P1, P21 (3-week-old), and P49 (7-week-old) (means \pm SEM). ${ }^{* *} p<0.01$ versus (TL; $n=174$ for P1 CTL mice per group; $n=157$ for P1 STR mice per group; $n=28$ for P21 mice per group; $n=28$ for P49 mice per group. C, Basal and stressinduced levels of serum CS in 7-week-old adult offspring expressed as means \pm SEM ( $n=10$ for each group). The stress-evoked increase in serum CS was measured in mice that received 30 min of immobilization stress. $\boldsymbol{D}$, MR and GR mRNA levels in the hippocampus of 7-week-old adult offspring determined by in situ hybridization. R.O.D. are presented in arbitrary units ( $n=$ 5 for each group).

Data analysis. Analyses of the radial arm maze data for revisiting and omission errors, choice of an arm, and time spent in a single trial from the eight-arm maze tasks were statistically evaluated using repeatedmeasures (RM) ANOVA, followed by the Bonferroni's test as a post hoc comparison. Other data were analyzed by paired or unpaired Student's $t$ tests. A probability level of $p<0.05$ was considered statistically significant.

\section{Results}

Physiological parameters in maternally stressed mice

Serum CS levels in pregnant mice increased more than twofold after chronic restraint stress when examined at $18.5 \mathrm{dpc}$, confirming the stress-induced effects of this treatment (controls, $0.838 \pm 0.084$ vs stressed mice, $2.097 \pm 0.087 \mu \mathrm{g} / \mathrm{ml} ; p<0.01$; $n=5$ for each group). Serum norepinephrine also doubled in these mice (controls, $99.63 \pm 7.97$ vs stressed mice, $176.34 \pm$ $10.96 \mathrm{pg} / \mathrm{ml} ; p<0.01 ; n=4$ for each group).

When MR and GR mRNA levels in the fetal hippocampus were examined at $18.5 \mathrm{dpc}$ by in situ hybridization to determine whether maternal stress affects the fetal HPA axis, we found that MR mRNA was markedly reduced in the stress group, whereas GR mRNA was not altered significantly (Fig. 1A). This finding 
implies that the fetal HPA axis was influenced by a stress-evoked, stimulation-induced feedback mechanism (Sapolsky et al., 1990). Pups born to stressed pregnant mice were weaned at $21 \mathrm{~d}$ of age and reared in an environment identical to that of the nonstressed controls. Stressed mothers exhibited similar maternal care behavior to control mice, such as licking and grooming (supplemental Fig. 1, available at www.jneurosci.org as supplemental material). With these normal care behaviors, the reduced birth weight of the pups from stressed mice rose during the suckling period to a control level by 3 weeks of age and was maintained to adulthood (Fig. $1 B$ ).

Before assessing the effects of maternal stress on hippocampal function, we examined several physiological parameters in 7-week-old (adult) offspring. Basal and stress-induced serum CS levels were similar to those of controls (Fig. 1C), and in situ hybridization revealed that MR and GR mRNA levels in the hippocampus were also not significantly affected (Fig. $1 D$ ).

\section{Impaired spatial memory but normal S-R habit learning in maternally stressed adult offspring}

To examine whether chronic maternal stress has a long-lasting influence on hippocampus-dependent learning and memory, we assessed the effects of maternal stress on the performance of adult offspring in the spatial working memory version of the eight-arm radial maze task, which is known to be dependent on the hippocampus (Lanke et al., 1993; Hodges, 1996). In each session, mice had to visit each of the eight arms only once to earn the greatest reward, because reentry of an arm already visited was not rewarded and was counted as a working memory error. In this task, animals had to rapidly establish and maintain memory of visited arms based on single within-trial exposures and to suppress interference from the memory of previous trials. The mice were trained one session per day for $12 \mathrm{~d}$. The performance of both control and maternally stressed mice improved over training by reducing the numbers of revisiting errors (omnibus RMANOVA; $F_{(11,165)}=10.33, p<0.0001$; for control mice, $F_{(11,88)}=$ $9.42, p<0.0001$; and for maternally stressed mice, $F_{(11,77)}=3.85$, $p<0.0002$ ) (Fig. 2A). However, the maternally stressed mice showed a significant difference in revisiting errors compared with controls $\left(F_{(1,15)}=30.17, p<0.0001\right.$ between groups). They exhibited impaired learning and made significantly more revisiting errors than controls (days $4-9$ and $11-12, p<0.05$ by Bonferroni's test) (Fig. 2A). The number of different arm choices in the first eight entries (Fig. $2 B$ ) is another measure of working memory performance. Although both groups showed an increase in the numbers of correct choices $\left(F_{(11,88)}=2.32, p<0.0145\right.$ for controls; $F_{(11,77)}=2.99, p<0.0023$ for maternally stressed mice), control mice also improved significantly more than maternally stressed mice by this measure $\left(F_{(11,165)}=4.60, p<0.0008\right.$ for day sessions; $F_{(1,15)}=9.73, p<0.007$ for group differences). Bonferroni's test revealed that there were significant differences between two groups on days $4-7$ ( $p<0.05)$. There were no interactions between groups and day sessions both in the numbers of revisiting errors $\left(F_{(11,165)}=1.11, p=0.3542\right)$ and different arm choices in the first eight entries $\left(F_{(11,165)}=0.90, p=0.488\right)$. Despite impairment of spatial working memory, both groups of mice made similar numbers of omission errors (visiting an arm but not taking the reward) (Fig. 2C). Both groups showed significant improvement in reducing omission errors (omnibus RMANOVA; $F_{(11,165)}=9.09, p<0.0001$; for controls, $F_{(11,88)}=$ 7.654, $p<0.0001$; and for maternally stressed mice, $F_{(11,77)}=$ $3.018, p<0.0022$ ), but there was no significant difference between groups, indicating that the maternally stressed mice did not have any pronounced motivational impairment $\left(F_{(1,15)}=\right.$
A.

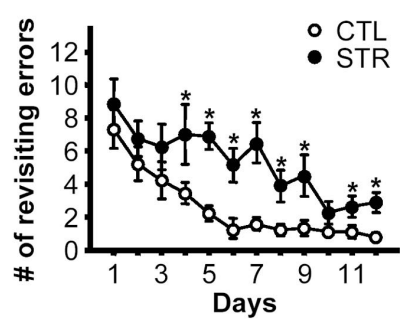

C.

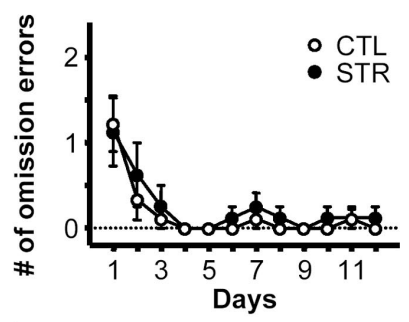

E.

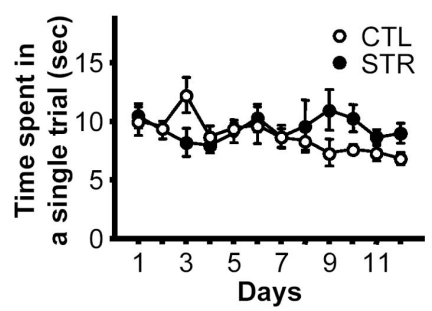

B.

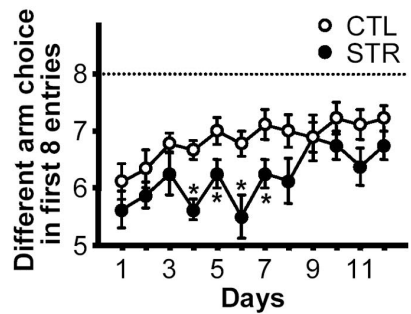

D.

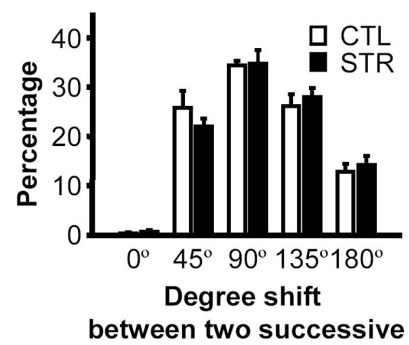
arm entries
Figure 2. Spatial working memory in the eight/eight version of the eight-arm radial maze. $\boldsymbol{A}$, Total number of revisiting errors (i.e., working memory errors) across training. $\boldsymbol{B}$, Number of different arms chosen in the first eight arm visits. $\boldsymbol{C}$, Number of omission errors, i.e., the arm was visited but the reward was not taken, as a measure of motivation. $\boldsymbol{D}$, Each arm visit was categorized into one of five groups according to the shift of angle between one arm and the next arm visited, and the percentage of arm visits in each group is shown. This plot is intended to reveal whether the animal has used a serial (nonspatial) search strategy, in which case there would be a higher percentage of $45^{\circ}$ shifts than of the others. $\boldsymbol{E}$, Mean running time spent in competing a single trial measured from entering an arm to returning to the central platform. $n=9$ for controls and $n=8$ for maternally stressed mice. ${ }^{*} p<0.05$ versus CTL on the same day.

$0.86, p=0.3682$ between groups; $F_{(11,165)}=0.21, p=0.9967$ for interactions). Figure $2 D$, which compares the percentage of each type of successive arm choice expressed as the angle between successive chosen arms, shows that the mice used a spatial search strategy rather than a nonspatial serial choice strategy; in both control and maternally stressed mice, the percentage of choosing adjacent $\left(45^{\circ}\right)$ arms was not greater than of other arms (90 and $\left.135^{\circ}\right)$. No significant difference in mean running time to complete a single trial (time taken from entering an arm to returning
A.

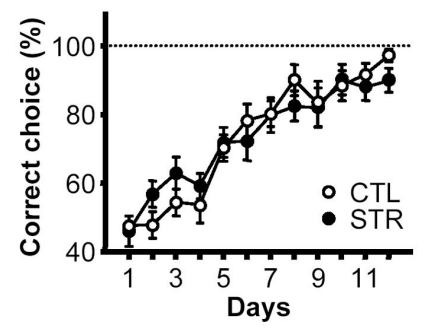

B.

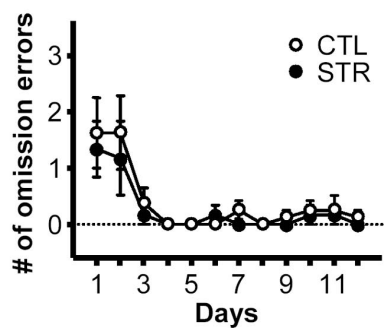

Figure 3. S-R habit task. $\boldsymbol{A}$, Percentage of correct choices (number of lit and baited arm choices/total arm choices $\times 100$ ) in the $S-R$ habit task version of the eight-arm maze task $(n=$ 8 for controls and $n=6$ for maternally stressed mice). $\boldsymbol{B}$, Number of omission errors. 
A.

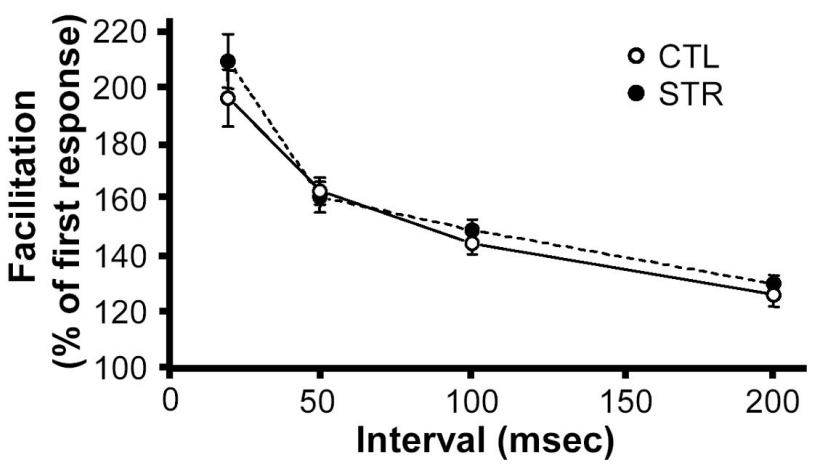

B.

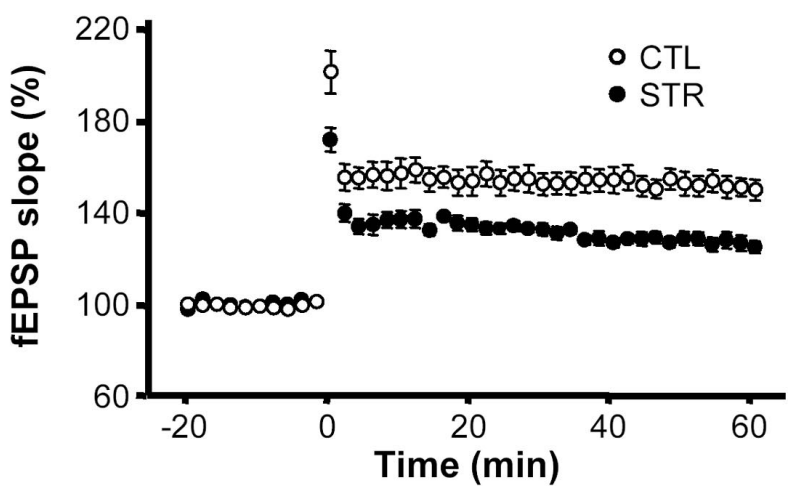

C.

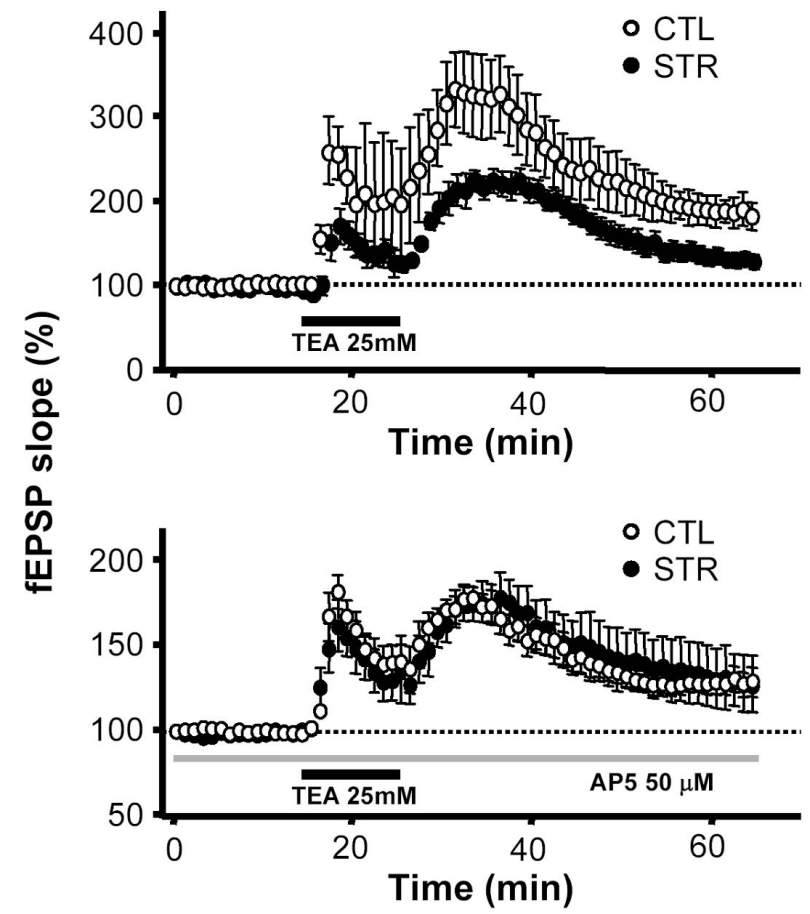

Figure 4. Synaptic plasticity in the CA1 area of hippocampal slices from 7- to 8-week-old adult offspring. A, PPF in the hippocampal CA1 area of control mice (open circles) and maternally stressed offspring (filled circles). The facilitation of the second fEPSP slope was compared with the first as a function of interpulse interval (10 slices from 3 control mice and 3 from maternally stressed offspring). $\boldsymbol{B}$, Tetanic stimulation-induced LTP in the CA1 area of hippocam$\mathrm{pal}$ slices. The slope of fEPSP was normalized to baseline (10 min before tetanic stimulation). Data from 12 slices from 6 control mice and 13 slices from 6 maternally stressed offspring are plotted as the mean \pm SEM slope of the fEPSP versus time. C, TEA-induced LTP in the absence or to center platform) was found between the two groups $\left(F_{(1,15)}=\right.$ $1.14, p=0.3021)$ or between day sessions $\left(F_{(11,165)}=1.29, p=\right.$ 0.2371) (Fig. 2E), although only control mice showed significant reductions in the running time with repetitions of sessions $\left(F_{(11,88)}=3.504, p=0.0004\right.$ for controls; and $F_{(11,77)}=0.6512$, $p=0.7792$ for maternally stressed mice).

In the next experiment, control and maternally stressed mice were subjected to a dorsal striatum-dependent but hippocampus-independent S-R habit task, another version of the eight-arm maze task (see Materials and Methods) (Packard et al., 1989; McDonald and Hong, 2004). Despite their impaired spatial working memory, maternally stressed mice produced a similar learning curve to that of the controls (omnibus RM-ANOVA; $F_{(1,12)}=0.00, p=0.9847$ between groups; $F_{(11,132)}=29.75, p<$ 0.0001 for days; and $F_{(11,132)}=0.91, p=0.5327$ for interactions; for the effect of day sessions on each group, $F_{(11,77)}=18.81, p<$ 0.0001 for controls; and $F_{(11,55)}=13.53, p<0.0001$ for maternally stressed mice) (Fig. $3 A$ ). Mice in both groups reached a criterion of $85 \%$ or higher in the accuracy of their choice of lit and baited arms within $10 \mathrm{~d}$ (Fig. $3 A$ ) and had similar levels of omission errors (omnibus RM-ANOVA; $F_{(1,12)}=0.51, p=0.4877$ between groups; $F_{(11,132)}=7.50, p<0.0001$ for days; and $F_{(11,132)}=$ $0.18, p=0.9983$ for interactions; $F_{(11,77)}=4.675, p<0.0001$ for controls; and $F_{(11,55)}=3.461, p<0.002$ for stressed animals) (Fig. $3 B$ ), suggesting normal striatum-dependent $\mathrm{S}-\mathrm{R}$ learning by the maternally stressed mice.

Synaptic plasticity in the CA1 area of hippocampal slices Synaptic plasticity in the hippocampus is strongly correlated with spatial memory and is therefore regarded as the cellular basis of this type of memory (Milner et al., 1998). To see whether hippocampal synaptic plasticity was affected by maternal stress, we performed a series of electrophysiological experiments in the CA1 area of hippocampal slices from male adult offspring of 7-8 weeks of age. Paired-pulse facilitation (PPF), a measure of presynaptic efficacy, was not modified in the CA1 area of hippocampal slices of the maternally stressed adult offspring when two identical stimuli were delivered in any of the four different interstimulus intervals (20,50,100, and $200 \mathrm{~ms}$ ) (Fig. 4A), indicating that presynaptic $\mathrm{Ca}^{2+}$ mobilization and neurotransmitter release were normal in these animals. In addition to presynaptic efficacy, neither the basal synaptic activity nor the input-output relationships was significantly different between controls and maternally stressed mice. EPSPs slopes by different stimuli intensities were $0.47 \pm 0.1 \mathrm{mV} / \mathrm{ms}$ (at $60 \mu \mathrm{A}$ ), $0.65 \pm 0.17 \mathrm{mV} / \mathrm{ms}$ (at $80 \mu \mathrm{A}$ ), and $1.09 \pm 0.26 \mathrm{mV} / \mathrm{ms}($ at $120 \mu \mathrm{A})$ in the control mice and $0.39 \pm$ $0.07,0.57 \pm 0.11$, and $1.13 \pm 0.17 \mathrm{mV} / \mathrm{ms}$, respectively, at the same intensities in maternally stressed mice $(n=4$ slices from different mice of each group). We found, however, that, in the hippocampal CA1 area, LTP, an activity-dependent and longlasting increase in synaptic efficacy, was greatly affected by maternal stress. The magnitude of LTP 60 min after tetanic stimulation of Schaffer collateral commissural fibers was significantly reduced in the hippocampal CA1 area of the maternally stressed

\section{$\leftarrow$}

presence of $50 \mu \mathrm{m} \mathrm{AP}-5$. Application of TEA ( $25 \mathrm{~mm}$ for $10 \mathrm{~min}$ ) induced LTP of fEPSP in the CA1 area of hippocampal slices ( 6 slices from 4 control mice; open circles in top). The degree of potentiation was lower in maternally stressed offspring than in control mice ( 5 slices from 4 maternally stressed mice; filled circles in top). Pretreatment with AP- 5 partially attenuated the TEA-induced LTP ( 6 slices from 3 mice; open circles in bottom). The reduction of TEA-induced LTP after AP-5 was not significant in the maternally stressed offspring ( 6 slices from 3 mice; filled circles in bottom). 
CTL

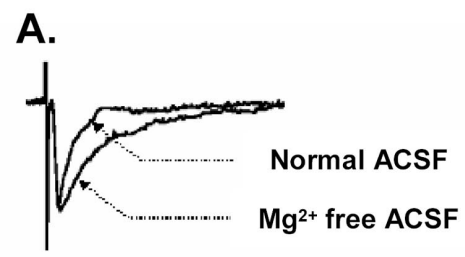

B.

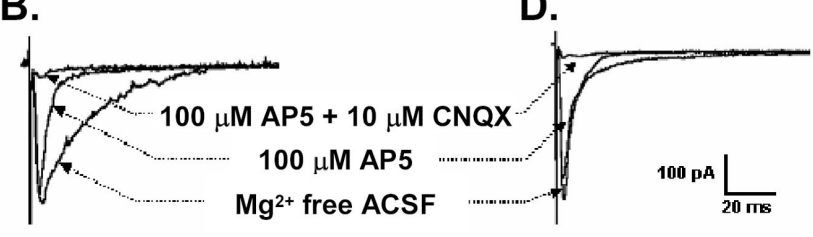

Figure 5. Evoked synaptic currents in CA1 neurons of controls and maternally stressed offspring. Whole-cell patch-clamp recording was performed at a holding potential of $-60 \mathrm{mV}$ in normal ACSF and $\mathrm{Mg}^{2+}$-free ACSF in each group ( $A, 4$ neurons from 3 control mice; $C, 3$ neurons from 2 maternally stressed offspring). In the bottom panels, evoked EPSC was first recorded in $\mathrm{Mg}^{2+}$-free ACSF and subsequently in the presence of AP-5 and CNQX. B, The slow component of the EPSC from control neurons was lowered by $100 \mu \mathrm{M}$ AP-5 and the fast component that remained disappeared after additional treatment with $10 \mu \mathrm{M}$ CNQX ( $n=12$ neurons from 8 control mice). D, No AP-5-sensitive slow component was observed in 10 neurons from 6 maternally stressed offspring.

adult offspring (control, $160.3 \pm 0.5 \%, n=12$ slices from 6 mice; stressed, $128.6 \pm 0.3 \%, n=13$ slices from 6 mice; $p<0.01$ vs control) (Fig. $4 B$ ). We measured another form of LTP induced by brief application of TEA ( $\mathrm{K} \mathrm{K}^{+}$channel blocker). The extent of LTP measured 40 min after a 10 min treatment with TEA was much lower in the maternally stressed adult offspring than in the control mice (control, $181.0 \pm 17.0 \%, n=6$ slices from 4 mice; stressed, $129.7 \pm 7.5 \%, n=5$ slices from 4 mice; $p<0.05$ vs control) (Fig. 4C). In the presence of the competitive NMDA receptor antagonist D,L-2-amino-5-phosphonopetanoic acid (AP-5), LTP was reduced $(p<0.05)$ to $131.5 \pm 7.2 \%$ in normal mice ( $n=6$ slices from 3 mice); in contrast, no reduction was observed in the maternally stressed offspring. TEA-induced LTP in the CA1 area of hippocampal slices consists of an NMDA receptor-dependent and voltage-sensitive calcium channeldependent LTP component (Hanse and Gustafsson, 1994). Hence, our results indicate that the reduced LTP may be NMDA receptor dependent. We therefore further delineated the NMDA receptor-mediated EPSCs in the hippocampal CA1 pyramidal neurons of 3-week-old mice by means of whole-cell patch-clamp recordings. EPSCs in normal hippocampal neurons had kinetically distinct fast and slow components. The slow component was completely blocked by the addition of $1.3 \mathrm{mM} \mathrm{Mg}^{2+}$, whereas the fast component remained unchanged (Fig. $5 A$ ). This was consistent with previous studies showing that the slow component results from NMDA receptor activation (McBain and Mayer, 1994). The slow component was also markedly shortened by $\mathrm{AP}-5$, and the remaining fast component was blocked by 6-cyano-7-nitro-quinoxaline-2,3-dione (CNQX), a non-NMDA receptor antagonist (Fig. 5B). EPSCs were also apparent in the CA1 neurons of maternally stressed offspring, but they differed from those of control mice. The slow component was absent, whereas $\mathrm{Mg}^{2+}$ - and AP-5-inhibitable EPSCs with fast decay were maintained. The AP-5-insensitive fast component was also blocked by CNQX in the stressed animals (Fig. 5C,D). These results demonstrate that NMDA receptor-mediated postsynaptic currents are impaired in the maternally stressed offspring.

\section{Synaptic NMDA receptor complex is reduced in the} hippocampi of maternally stressed offspring

Because electrophysiological studies pointed to defects in the functional NMDA receptor complex, we examined levels of the mRNAs for NR1, NR2A, and NR2B, major subunits of NMDA receptors in the hippocampal region (Monyer et al., 1994), at $18.5 \mathrm{dpc}$, 3-weeks, and 7-weeks of age by in situ hybridization (Fig. 6). Expression of these subunits increased with age, NR2A showing the greatest increase. However, there were no significant differences between controls and maternally stressed mice ( $p>0.05$ by unpaired $t$ test). In addition, Northern blot analyses revealed that mRNAs for other NMDA receptor subunits such as NR2C, NR2D, and NR3 in the adult hippocampus were also unaffected by maternal stress (supplemental Fig. 2, available at www.jneurosci.org as supplemental material). The protein levels of the subunits themselves were also essentially the same in the two groups (Fig. 7A). These results indicate that impairment of NMDA-mediated LTP and EPSC is attributable to some causes other than reduced levels of NMDA receptor subunits. Because the functional NMDA receptors are thought to reside on the cell surface, including synapses, we examined this component in the hippocampi of control and maternally stressed offspring. In contrast to protein levels in whole-cell lysates, the synaptic contents of NR1, a core subunit of NMDA receptor, and of NR2B were significantly reduced in the hippocampus by maternal stress (normalized mean NR1 R.O.D. of stressed mice, $55.56 \pm 4.12 \%$ of controls, $p<0.01$ by paired $t$ test; NR2B of stressed mice, $64.61 \pm 4.94 \%$ of control, $p<$ $0.01 ; n=4$ for each group) (Fig. $7 B, C$ ). Reduced synaptic levels of NR1 and NR2B were also shown by coimmunoprecipitation experiments. PSD95 protein is an NMDA receptor-anchoring molecule, which plays a crucial role in the surface expression and synaptic localization of the receptor by interacting with the C-terminal domain of NR2 and certain splice variants of NR1 (Kornau et al., 1995). As shown in Figure 7A, maternal stress had no effect on PSD95 expression. However, immunoprecipitation experiments with an anti-PSD95 antibody revealed that the amounts of NR1 and NR2B subunits in the NMDA receptor complexes associated with PSD95 were reduced in hippocampal lysates from the maternally stressed adult mice (normalized mean NR1 R.O.D. of stressed mice, $60.69 \pm$ $6.84 \%$ of control, $p<0.01$ by paired $t$ test; NR2B of stressed mice, $53.52 \pm 4.55 \%$ of control, $p<0.01 ; n=5$ for each group) (Fig. $7 D$, first and second lanes). Interestingly, early adoption by a mother of the other group on the second postnatal day (adopted CTL and STR, respectively) could not prevent this effect, indicating that reduced synaptic NR1 and NR2B is attributable to prenatal circumstances rather than differences in the neonatal period, such as less satisfactory maternal care (Fig. 7D, third and fourth lanes). The synaptic localization of the NR2A subunit was not affected in hippocampus of maternally stressed offspring, suggesting that maternal stress may cause both quantitative and qualitative alterations of the NMDA receptor complex in synapses.

\section{Sucrose density gradient centrifugation of NR1 subunits}

The NMDA receptor is initially formed by oligomerization of its subunits and further clustered at the synapse, forming a large complex containing many proteins (Husi and Grant, 2001). To confirm the reduction of synaptic NR1-containing NMDA receptors, hippocampal lysates from both groups were fractionated by sucrose gradient ultracentrifugation. Immunoblot analysis revealed two peaks of NR1 immunoreactivities. The position of the lower density peak was close to that of the single peak detected in denatured hippocampal lysates, indicating that this peak represents the naive or intracellular pool of NR1 subunits, not clustered into postsynaptic densities (Fig. 8). The ratio of the higher 
$18.5 \mathrm{dpc}$

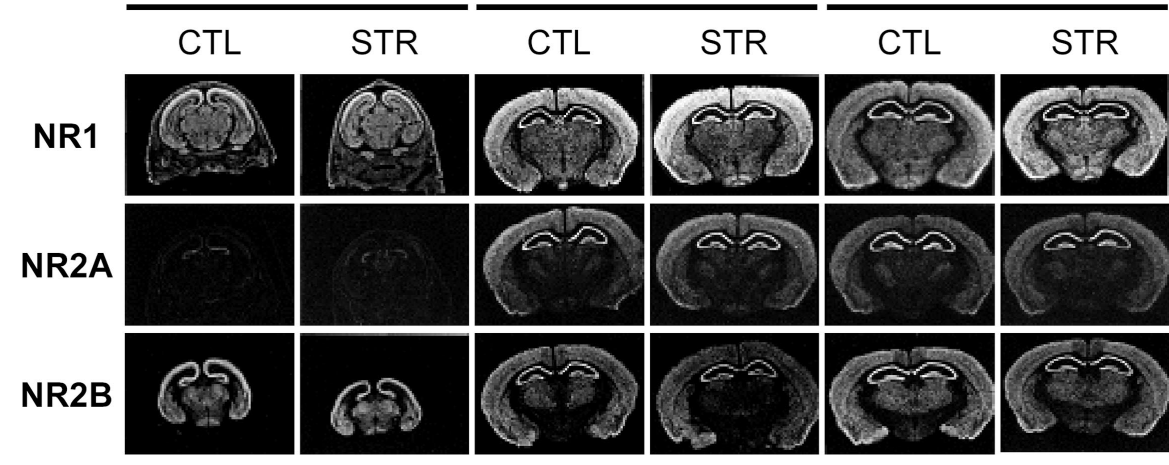

mice (Fig. 9B). These results suggest that impaired synaptic localization of the NMDA receptor in the hippocampi of adult maternally stressed offspring is associated with a defect at the level of receptor assembly, particularly the interaction between NR1 and NR2B subunits.

\section{Discussion}

The present study was designed to elucidate whether chronic stress to pregnant mothers affects their offspring in later life. It was, indeed, the case that maternal stress retarded fetal growth and resulted in low birth weight of pups. When stressed pups were reared to adulthood in an environment identical to that of control animals, they exhibited impairment of hippocampus-dependent spatial memory, as well as of NMDA receptor-mediated synaptic plasticity in the hippocampal CA1 area. Although the several previous studies noted that offspring of mothers experiencing stress during pregnancy could display behavioral and/or physiological abnormalities with structural and morphological changes in the brain, our study addresses and clarifies the long-lasting influence of chronic maternal stress on the hippocampus of adult offspring at cellular and molecular levels. We believe that this mouse model of maternal stress is rather unique because it will permit the use of genetic approaches to further clarify the

density peak to the lower one in the hippocampal lysates from maternally stressed offspring was lower than that observed in control mice (control, $1.337 \pm 0.078$ vs stress, $0.662 \pm 0.091 ; p<$ 0.01 by paired $t$ test; $n=5$ for each group), confirming that the number of NR1-containing NMDA receptor complexes is reduced in the hippocampi of maternally stressed offspring. There was no significant difference in the distribution of PSD95 immunoreactivity in the sucrose density gradients from control and stressed mice (supplemental Fig. 3, available at www.jneurosci. org as supplemental material).

\section{Interaction between the NR1 and NR2B subunits is reduced} The NMDA receptor is a heteromeric receptor composed of a core NR1 subunit in combination with one or more NR2 subunits and, less commonly, an NR3 subunit (McBain and Mayer, 1994; Das et al., 1998). Because the interaction between these subunits is crucial for surface expression and synaptic clustering of the receptor (Barria and Malinow, 2002; Fukaya et al., 2003), we looked for a possible defect at the level of receptor assembly. For this purpose, we examined the interaction between the NR1 and NR2 subunits by coimmunoprecipitation with anti-NR1 or NR2 antibodies. NR2A immunoreactivity associated with the NR1 subunit was virtually unchanged by maternal stress. However, the interaction between NR1 and the NR2B subunit was apparently decreased in the hippocampi of maternally stressed mice (normalized mean NR1 R.O.D. associated with NR2B in stressed mice, $40.41 \pm 11.09 \%$ of control, $p<0.05$ by paired $t$ test; NR2B associated with NR1 in stressed mice, $43.47 \pm 8.02 \%$ of control, $p<0.05 ; n=4$ for each group) (Fig. 9A). In contrast, this interaction was not altered in the cerebral cortices of stressed effects of chronic stress during pregnancy.

In rodents, the hippocampus has long been recognized as a critical structure for encoding spatial information (Milner et al., 1998; Kesner et al., 2004). Our behavioral studies with the eight-arm radial maze task demonstrated impairment of spatial working memory, which requires a fully functional hippocampus (Lanke et al., 1993; Hodges, 1996; Pothuizen et al., 2004), in maternally stressed adult offspring. As shown in Figure $2 A$, the impaired ability of maternally stressed mice to learn to reduce arm-revisiting errors as the training proceeds in the radial arm maze indicates that they have deficits in this one-experience learning. Because there were no significant differences in the number of omission errors and the running time per trial between the two groups, it is unlikely that the impaired learning in the eight-arm maze is attributable to problems in attention/motivation and/or motor activity. Furthermore, the normal striatum-dependent S-R habit memory of these mice also strongly suggests that the learning deficits in the spatial memory version of the radial arm maze derive from impaired hippocampal functions.

Electrophysiological experiments on hippocampal brain slices from maternally stressed adult offspring showed silent features. Because the PPF was normal in maternally stressed mice and because PPF is related to presynaptic $\mathrm{Ca}^{2+}$ mobilization and neurotransmitter release (Jiang et al., 2000), it seems that presynaptic function was not affected by maternal stress. Conversely, tetanic stimulus-induced LTP in the hippocampal CA1 area was markedly decreased in these animals. Our observation that TEA-induced LTP was reduced in the maternally stressed mice and that the remaining capacity was AP-5 insensitive (Fig. 4C) indicates that there is impair- 
ment of NMDA receptor-mediated LTP in the hippocampus of the maternally stressed adult offspring. TEA-induced LTP in the CA1 area of hippocampal slices consists of NMDA receptor-dependent and voltagedependent calcium channel-mediated component (Hanse and Gustafsson, 1994). Furthermore, whole-cell patch-clamp recordings demonstrated the absence of an NMDA receptor-mediated slow component of EPSCs in the maternally stressed 3-weekold offspring. Collectively, these results indicate that the reduced LTP found in maternally stressed hippocampi is related to the dysfunction of the NMDA receptor.

NMDA receptors are heteromeric assemblies of a core NR1 subunit and various modulatory NR2 subunits. In the hippocampus, NR2A and NR2B subunits serve as the major NR2 components in association with NR1 subunits (Monyer et al., 1994). In an attempt to relate the reduced NMDA receptor-dependent synaptic plasticity with NMDA receptor gene expression, we measured the mRNA and protein levels of the NMDA receptor subunits in the hippocampus. There were no significant differences in the levels of any of the NMDA receptor subunits between controls and maternally stressed mice. However, because the synaptic NMDA receptor complex appeared to be altered in some way, we used three experimental approaches to specify the possible changes in synaptic NMDA receptor (Figs. 7, 8). Each of the approaches pointed to the presence of a reduced number of NMDA receptors in the synapses, in particular, of receptors containing NR1 and NR2B. Because the NMDA receptor is a ligand-gated ion channel, its surface expression is crucial for function. At the cell surface, including the synapse, NMDA receptors are anchored and clustered by a variety of scaffolding proteins, forming larger complexes (Husi and Grant, 2001). PSD95 is a major protein anchoring and organizing the NMDA receptor complex in hippocampal synapses by virtue of its interaction with the C-terminal domains of NR2 subunits and of some alternative splicing variants of the NR1 subunit (Kornau et al., 1995). Therefore, the decrease in NR1 suggests that the number of functional NMDA receptors in the synapse is reduced in the adult hippocampus as a result of maternal stress. In view of the fact that insertion of NMDA receptor subunits into the synapses from the intracellular pool is completely dependent on preassembly of the subunits to form a mature NMDA receptor complex (Barria and Malinow, 2002; Fukaya et al., 2003), the impaired synaptic localization of NMDA receptors is most likely attributable to reduced interaction between the NR1 and NR2B subunits, as shown in Figure 9.

It is of interest that synaptic NR2B, but not NR2A, was reduced because this implies that the composition of the NR2 subunits in NMDA receptor complex is also affected by maternal stress. Subunit composition is a critical determinant of function
B.

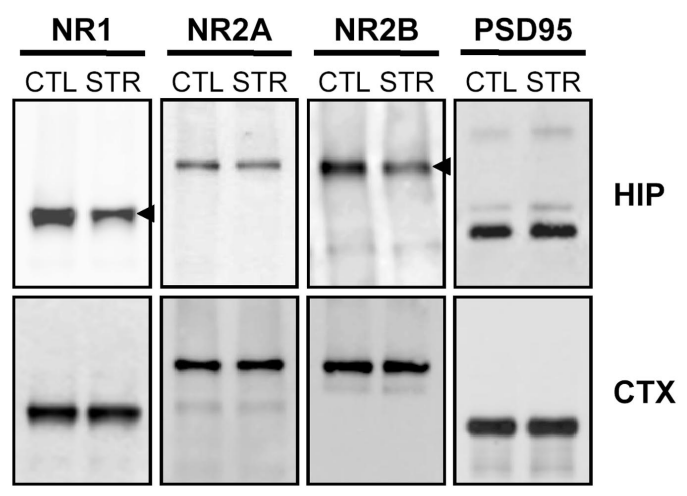

D.

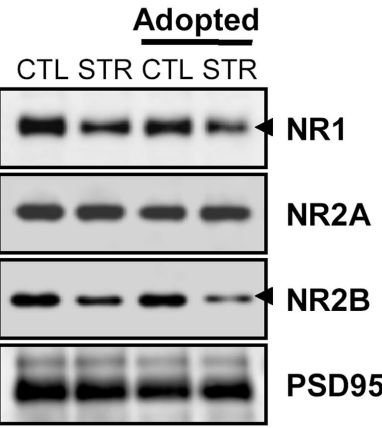

IP: PSD95

Figure 7. Effect of maternal stress on expression of NMDA receptor subunits and their synaptic localization. $\boldsymbol{A}$, Hippocampal lysates prepared from control and maternally stressed mice at the age of 3 and 8 weeks were resolved on $8 \%$ SDS-polyacrylamide 作 and electrotransferred to PVDF membranes. Immunoblot analyses were performed using anti-NR1, NR2A, NR2B, PSD95, and determined by densitometric analyses and normalized with those for PSD95. The results are presented as means \pm SEM (R.0.D.) of CTL for each comparison ( ${ }^{* *} p<0.01$ by paired $t$ test; $n=4$ per each group). $\boldsymbol{D}$, Immunoprecipitation (IP) of PSD95 in the subunits associated with PSD95 were measured by immunoblotting and probing with anti-NR1, NR2A, NR2B, and PSD95 antibodies. Arrowheads indicate immunoreactive bands whose intensities differed between control and maternally stressed mice.

in the NMDA receptor. Recombinant NR1-NR2B receptors expressed in Xenopus oocytes elicited more robust and prolonged $\mathrm{Ca}^{2+}$ currents than NR1-NR2A receptors (Vicini et al., 1998; Wyllie et al., 1998). Similarly, NMDA receptor-mediated EPSCs showing fast decay have been reported in cultured hippocampal neurons from NR2B-deficient mice (Tovar et al., 2000). Indeed, our maternally stressed mice retained $\mathrm{Mg}^{2+}$ - and AP-5dependent fast decaying EPSCs but lacked the slow component. These results also strongly imply defects in NR2B-containing NMDA receptors, in accord with the biochemical evidence. Moreover, several lines of evidence point to the significance of the NR2A/NR2B ratio in hippocampal function. For instance, neonatal treatment of rats with dexamethasone led to a reduction of the synaptic NR2B subunit and impaired spatial learning and hippocampal synaptic plasticity (Kamphuis et al., 2003). In addition, selective antisense knock-down of the NR2B subunit in the rat hippocampus was sufficient to abolish LTP in the hippocampal CA1 area, thereby impairing spatial learning (Clayton et al., 2002). The present results point to alterations in both amount and composition of the synaptic NMDA receptor complex, 
Density

Fraction No. 2

13
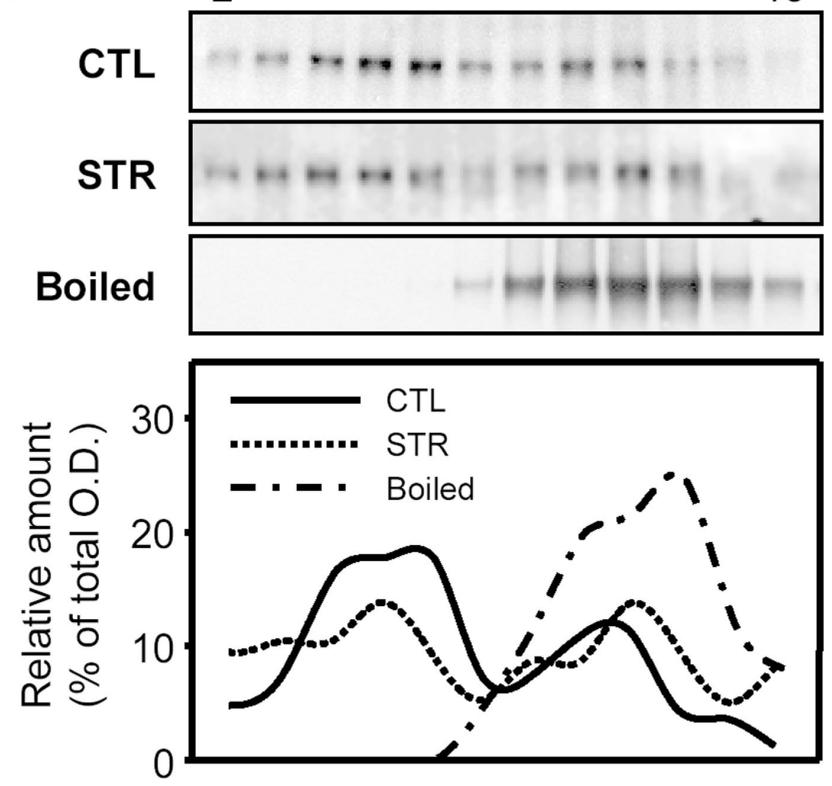

Figure 8. Immunoblot analysis of sucrose density gradient fractions from hippocampal lysates of control and maternally stressed mice at the age of 8 weeks. Twenty hippocampi from each group were lysed in the presence of $2 \%$ Triton X-100. Sucrose density gradient ultracentrifugation was performed as described in Materials and Methods. Representative immunoblots and plots showing the distribution of NR1 immunoreactivities are presented.

which may contribute to the impaired hippocampal functions in maternally stressed mice.

Electrophysiological parameters in the hippocampus can be modified by a variety of stresses and their mediators. For instance, acute stress modifies NMDA receptor-mediated LTP (Kim et al., 1996), and CS affects LTP induction in an inverted U-type dose-dependent manner (Diamond et al., 1992). In our study, however, serum CS levels in the maternally stressed offspring were observed within the normal range (in the absence of any additional stress), and it seems most unlikely that the reduced LTP was just attributable to altered serum CS level. Rather, our data strongly suggest an intrinsic defect in NMDA receptor-mediated LTP in maternally stressed adult offspring, despite normal circulating CS levels. Notably, differential regulatory mechanisms were suggested to exist in the synaptic insertion of NR2A and NR2B: synaptic insertion of NR2B-containing receptor is not promoted by increased NR2B expression, whereas increased expression of NR2A enhanced trafficking of NR2A-containing receptors into synapses (Barria and Malinow, 2002), indicating that there may be an NR2B-specific regulatory mechanism. In accordance with this notion, several lines of evidence suggested such a differential regulation between NR2A and NR2B-containing NMDA receptors. In addition to programming effects of neonatal exposure to a synthetic glucocorticoid as mentioned previously (Kamphuis et al., 2003), administration of 6-hydroxydopamine to adult rats promoted the selective redistribution of NR1 and NR2B subunits from the membrane to the cytoplasmic compartment, leading to the reduction of surface NR1/NR2B-containing receptors (Dunah et al., 2000). Moreover, adoption experiments and the normal care behavior of the stressed mother suggest that the alterations in the synaptic NMDA receptor complex are attributable to prenatal

\section{A. HIP}

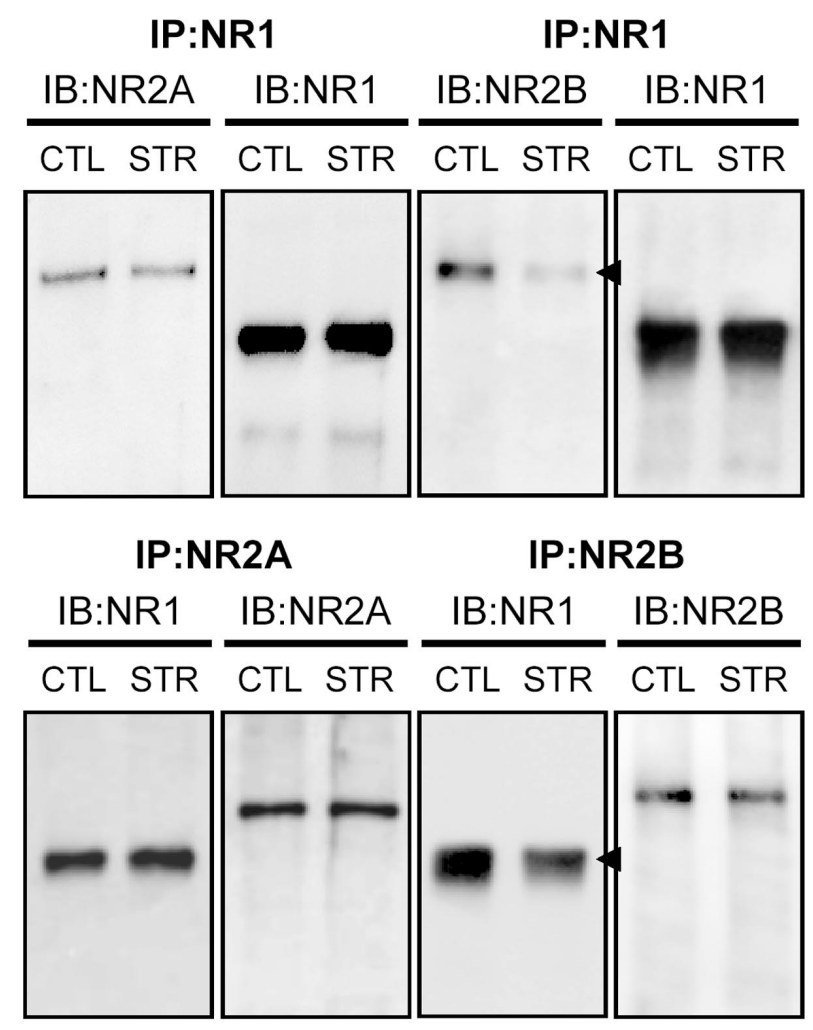

\section{B. CTX}

IP:NR2A

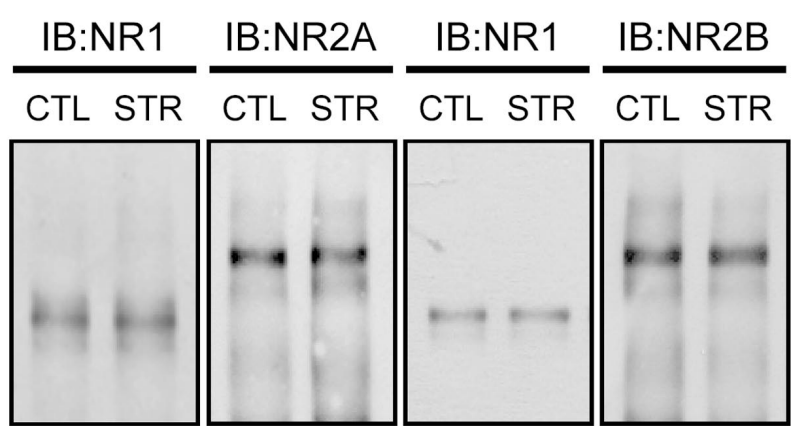

Figure 9. Interaction between NR1 and NR2 subunits. $A$, Coimmunoprecipitation (IP) studies using an anti-NR1, NR2A, or NR2B antibodies in 8-week-old control and maternally stressed mice. Interaction between NR1 and NR2 subunits was assessed by immunoblotting (IB). Arrowheads indicate immunoreactive bands whose intensities differed between control and maternally stressed mice. $\boldsymbol{B}$, Coimmunoprecipitation of NR1 with NR2 was examined in cell lysates from the cerebral cortex (CTX). These experiments were independently conducted four times, and similar results were obtained. Representative blots are shown here.

factors evoked by the maternal stress. Therefore, it is most probable that maternal factors including maternal stress hormones may affect a certain regulatory system specific for the receptor assembly and synaptic trafficking of NR2B-containing NMDA receptors, and this was persistently programmed in the hippocampi of our maternally stressed mice. The exact molecular target of maternal stress regarding the regulation of NMDA receptors should be further elucidated.

In summary, our data demonstrate that maternal stress im- 
pairs the function of postsynaptic NMDA receptors specifically in the hippocampus, thereby reducing hippocampal LTP. The molecular and electrophysiological evidence is consistent with impairment of spatial learning and memory in the adult offspring of stressed dams. Thus, maternal stress during fetal development appears to cause long-lasting changes in hippocampal mechanisms. Although prenatal brain development is based on a genetic blueprint, our results show that the fetal environment can also have a profound influence on brain development that may persist into and be manifested in adulthood.

\section{References}

Barbazanges A, Piazza PV, Le Moal M, Maccari S (1996) Maternal glucocorticoid secretion mediates long-term effects of prenatal stress. J Neurosci 16:3943-3949.

Barria A, Malinow R (2002) Subunit-specific NMDA receptor trafficking to synapses. Neuron 35:345-353.

Chung S, Son GH, Park SH, Park E, Lee KH, Geum D, Kim K (2005) Differential adaptive responses to chronic stress of maternally stressed male mice offspring. Endocrinology 146:3202-3210.

Clayton DA, Mesches MH, Alvarez E, Bickford PC, Browning MD (2002) A hippocampal NR2B deficit can mimic age-related changes in long-term potentiation and spatial learning in the Fischer 344 rat. J Neurosci 22:3628-3637.

Das S, Sasaki YF, Rothe T, Premkumar LS, Takasu M, Crandall JE, Dikkes P, Conner DA, Rayudu PV, Cheung W, Chen HS, Lipton SA, Nakanishi N (1998) Increased NMDA current and spine density in mice lacking the NMDA receptor subunit NR3A. Nature 393:377-381.

De Kloet ER, Verugdnenhil E, Oitzl MS, Joels M (1998) Brain corticosteroid receptor balance in health and disease. Endocr Rev 19:269-301.

Diamond DM, Bennett MC, Fleshner M, Rose GM (1992) Inverted-U relationship between the level of peripheral corticosterone and the magnitude of hippocampal primed burst potentiation. Hippocampus 2:421-430.

Dunah AW, Wang Y, Yasuda RP, Kameyama K, Huganir RL, Wolfe BB, Standaert DG (2000) Alterations in subunit expression, composition, and phosphorylation of striatal $\mathrm{N}$-methyl-D-aspartate glutamate receptors in a rat 6-hydroxydopamine model of Parkinson's disease. Mol Pharmacol 57:342-352.

Francis D, Diorio J, Liu D, Meaney MJ (1999) Nongenomic transmission across generations of maternal behavior and stress responses in the rat. Science 286:1155-1158.

Fukaya M, Kato A, Lovett C, Tonegawa S, Watanabe M (2003) Retention of NMDA receptor NR2 subunits in the lumen of endoplasmic reticulum in targeted NR1 knockout mice. Proc Natl Acad Sci USA 100:4855-4860.

Hanse E, Gustafsson B (1994) TEA elicits two distinct potentiations of synaptic transmission in the CA1 region of the hippocampal slice. J Neurosci 14:5028-5034.

Hodges H (1996) Maze procedures: the radial-arm and water maze compared. Brain Res Cogn Brain Res 3:167-181.

Husi H, Grant SG (2001) Proteomics of the nervous system. Trends Neurosci 24:259-266.

Jiang L, Sun S, Nedergaard M, Kang J (2000) Paired-pulse modulation at individual GABAergic synapses in rat hippocampus. J Physiol (Lond) 523:425-439.

Kamphuis PJ, Gardoni F, Kamal A, Croiset G, Bakker JM, Cattabeni F, Gispen WH, Van Bel F, Di Luca M, Wiegant VM (2003) Long-lasting effects of neonatal dexamethasone treatment on spatial learning and hippocampal synaptic plasticity: involvement of the NMDA receptor complex. FASEB J 17:911-913.

Kang SS, Son GH, Seong JY, Choi D, Kwon HB, Lee CC, Kim K (1998) Noradrenergic neurotoxin suppresses gonadotropin-releasing hormone $(\mathrm{GnRH})$ and $\mathrm{GnRH}$ receptor gene expression in ovariectomized and steroid-treated rats. J Neuroendocrinol 10:911-918.

Kesner RP, Lee I, Gilbert P (2004) A behavioral assessment of hippocampal function based on a subregional analysis. Rev Neurosci 15:333-351.

Kim JJ, Foy MR, Thompson RF (1996) Behavioral stress modifies hippocampal plasticity through $\mathrm{N}$-methyl-D-aspartate receptor activation. Proc Natl Acad Sci USA 93:4750-4753.

Kornau HC, Schenker LT, Kennedy MB, Seeburg PH (1995) Domain interaction between NMDA receptor subunits and the postsynaptic density protein PSD-95. Science 269:1737-1740.
Lanke J, Mansson L, Bjerkemo M, Kjellstrand P (1993) Spatial memory and stereotypic behaviour of animals in radial arm mazes. Brain Res 605:221-228.

Lemaire V, Koehl M, Le Moal M, Abrous DN (2000) Prenatal stress produces learning deficits associated with an inhibition of neurogenesis in the hippocampus. Proc Natl Acad Sci USA 97:11032-11037.

Levitt NS, Lindsay RS, Holmes MC, Seckl JR (1996) Dexamethasone in the last week of pregnancy attenuates hippocampal glucocorticoid receptor gene expression and elevates blood pressure in the adult offspring in the rat. Neuroendocrinology 64:412-418.

Lordi B, Patin V, Protais P, Mellier D, Caston J (2000) Chronic stress in pregnant rats: effects on growth rate, anxiety and memory capabilities of the offspring. Int J Psychophysiol 37:195-205.

Maccari S, Piazza PV, Kabbaj M, Barbazanges A, Simon H, Le Moal M (1995) Adoption reverses the long-term impairment in glucocorticoid feedback induced by prenatal stress. J Neurosci 15:110-116.

McBain CJ, Mayer ML (1994) N-methyl-D-aspartic acid receptor structure and function. Physiol Rev 74:723-760.

McDonald RJ, Hong NS (2004) A dissociation of dorso-lateral striatum and amygdala function on the same stimulus-response habit task. Neuroscience 124:507-513.

Milner B, Squire LR, Kandel ER (1998) Cognitive neuroscience and the study of memory. Neuron 20:445-468.

Miyakawa T, Yamada M, Duttaroy A, Wess J (2001) Hyperactivity and intact hippocampus-dependent learning in mice lacking the $\mathrm{M}_{1}$ muscarinic acetylcholine receptor. J Neurosci 21:5239-5250.

Monyer H, Burnashev N, Laurie DJ, Sakmann B, Seeburg PH (1994) Developmental and regional expression in the rat brain and functional properties of four NMDA receptors. Neuron 12:529-540.

Moon IS, Apperson ML, Kennedy MB (1994) The major tyrosinephosphorylated protein in the postsynaptic density fraction is $N$-methylD-aspartate receptor subunit 2B. Proc Natl Acad Sci USA 91:3954-3958.

Nathanielsz PW (1999) Life in the womb: the origin of health and disease. New York: Promethean.

Packard MG, Hirsh R, White NM (1989) Differential effects of fornix and caudate nucleus lesions on two radial maze tasks: evidence for multiple memory systems. J Neurosci 9:1465-1472.

Pothuizen HH, Zhang WN, Jongen-Relo AL, Feldon J, Yee BK (2004) Dissociation of function between the dorsal and the ventral hippocampus in spatial learning abilities of the rat: a within-subject, within-task comparison of reference and working spatial memory. Eur J Neurosci 19:705-712.

Sapolsky RM, Armanini MP, Packan DR, Sutton WS, Plotsky PM (1990) Glucocorticoid feedback inhibition of adrenocorticotropic hormone secretagogue release. Relationship to corticosteroid receptor occupancy in various limbic sites. Neuroendocrinology 51:328-336.

Stratakis CA, Chrousos GP (1995) Neuroendocrinology and pathophysiology of the stress system. In: Stress: basic mechanisms and clinical implications (Chrousos GP, McCarty R, Pacak K, Cizza G, Sternberg E, Gold PW, Kvetnansky R, eds), pp 1-18. New York: The New York Academy Science.

Sun W, Park KW, Choe J, Rhyu IJ, Kim IH, Park SK, Choi B, Choi SH, Park SH, Kim H (2005) Identification of novel electroconvulsive shockinduced and activity-dependent genes in the rat brain. Biochem Biophys Res Commun 327:848-856.

Tovar KR, Sprouffske K, Westbrook GL (2000) Fast NMDA receptormediated synaptic currents in neurons from mice lacking the epsilon2 (NR2B) subunit. J Neurophysiol 83:616-620.

Vallee M, Mayo W, Dellu F, Le Moal M, Simon H, Maccari S (1997) Prenatal stress induces high anxiety and postnatal handling induces low anxiety in adult offspring: correlation with stress-induced corticosterone secretion. J Neurosci 17:2626-2636.

Vicini S, Wang JF, Li JH, Zhu WJ, Wang YH, Luo JH, Wolfe BB, Grayson DR (1998) Functional and pharmacological differences between recombinant $N$-methyl-D-aspartate receptors. J Neurophysiol 79:555-566.

Welberg LA, Seckl JR (2001) Prenatal stress, glucocorticoids and the programming of the brain. J Neuroendocrinol 13:113-128.

Wyllie DJ, Behe P, Colquhoun D (1998) Single-channel activations and concentration jumps: comparison of recombinant NR1a/NR2A and NR1a/NR2D NMDA receptors. J Physiol (Lond) 510:1-18. 